\title{
The inverted trophic cascade in tropical plankton communities: Impacts of exotic fish in the Middle Rio Doce lake district, Minas Gerais, Brazil
}

\author{
Pinto-Coelho, RM. ${ }^{\mathrm{a} *}$, Bezerra-Neto, JF. ${ }^{\mathrm{b}}$, Miranda, $F^{\mathrm{b}}$, , Mota, TG. ${ }^{\mathrm{b}}$, Resck, ${ }^{\mathrm{b}}{ }^{\mathrm{b}}$, Santos, AM. ${ }^{\mathrm{c}}$, \\ Maia-Barbosa, PM. ${ }^{\mathrm{d}}$, Mello, NAST. ${ }^{\mathrm{d}}$, Marques, MM. ${ }^{\mathrm{e}}$, Campos, MO. ${ }^{\mathrm{e}}$ and Barbosa, FAR. ${ }^{\mathrm{e}}$ \\ áLaboratório de Gestão Ambiental de Reservatórios, Departamento de Biologia Geral, \\ Instituto de Ciências Biológicas, Universidade Federal de Minas Gerais - UFMG, \\ CP 486, CEP 31270-901, Belo Horizonte, MG, Brazil \\ 'Programa Programa de Pós-Graduação em Ecologia, Conservação e Manejo da Vida Silvestre, \\ Universidade Federal de Minas Gerais - UFMG, CP 486, CEP 31270-901, Belo Horizonte, MG, Brazil \\ 'Departamento de Biologia Geral, Centro de Ciências Biológicas e da Saúde, \\ Universidade Estadual de Montes Claros - UNIMONTES, \\ Rua Rui Braga, Campus Darcy Ribeiro, CEP 39401-089, Montes Claros, MG, Brazil \\ ${ }^{d}$ Laboratório de Ecologia do Zooplâncton, Departamento de Biologia Geral, Instituto de Ciências Biológicas, \\ Universidade Federal de Minas Gerais - UFMG, CP 486, CEP 31270-901, Belo Horizonte, MG, Brazil

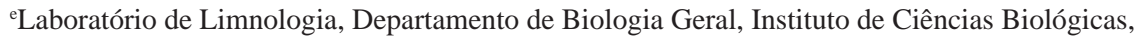 \\ Universidade Federal de Minas Gerais - UFMG, CP 486, CEP 31270-901, Belo Horizonte, MG, Brazil \\ *e-mail: rmpc@icb.ufmg.br
}

Received October 9, 2007 - Accepted October 9, 2007 - Distributed November 30, 2008

(With 6 figures)

\begin{abstract}
The present study deals with the ecological impacts of the introduction of two alien species of piscivorous fish in several lakes of the Middle Rio Doce lake district in Minas Gerais, Brazil. It was demonstrated that these effects were not restricted only to the fish community. The introduction of the predatory red piranha Pygocentrus nattereri and the tucunare Cichla cf. ocellaris caused not only a sharp decrease in the number of native fish species, but also major shifts in other trophic levels. Just after the fish were introduced, most lakes began to show conspicuous changes in phytoplankton species composition, in which Cyanophyceae gradually came to dominate. The zooplankton community lost several species, and in some cases, such as Lake Carioca, all the cladoceran species disappeared. On the other hand, invertebrate predators, represented by the dipteran Chaoboridae, boomed in the lake, with higher densities of exotic species, probably as a result of the "ecological release" by reduction of the original fish fauna. There was a general trend of species loss in different trophic levels. All these changes are apparently associated with decreases in water quality. The present situation in these lakes demands new approaches to the management and conservation of these ecosystems.
\end{abstract}

Keywords: exotic species, eutrophication, trophic cascade, zooplankton, introductions.

\section{A cascata trófica invertida em comunidades planctônicas tropicais: Impactos da introdução de peixes exóticos no distrito de lagos do médio rio Doce, MG}

\begin{abstract}
Resumo
O presente estudo trata dos impactos ecológicos da introdução de duas espécies invasoras de peixes piscívoros em diversos lagos da região lacustre do médio rio Doce em Minas Gerais, Brasil. Demonstrou-se que estes efeitos não se restringiram às comunidade de peixes. A introdução dos predadores Pygocentrus nattereri (piranha-vermelha) e Cichla cf. ocelaris (tucunaré) não só causou uma forte redução no número de espécies de peixes nativos, como também mudanças nos níveis tróficos inferiores. Pouco depois das introduções, a maioria dos lagos começou a mostrar alterações na comunidade fitoplanctônica, tais como o aparecimento da dominância de Cyanophyceae. A comunidade zooplanctônica perdeu diversas espécies e, em alguns casos, houve o desaparecimento de todas as espécies de cladóceros limnéticos, como é o caso da lagoa Carioca. Por outro lado, predadores invertebrados, representados pelos dípteros da família Chaoboridae, oresceram nos lagos com maiores densidades de espécies exóticas de peixes, provavelmente como resultado da "liberação ecológica" causada pela redução da ictiofauna original. Além de uma
\end{abstract}


tendência geral de perda de espécies em diferentes níveis tróficos, outras mudanças estão aparentemente associadas com a redução da qualidade de água. Dessa forma, esses ecossistemas estão necessitando urgentemente de novas abordagens nas estratégias de manejo e conservação.

Palavras-chave: espécies exóticas, eutrofização, cascata trófica, zooplâncton, introduções.

\section{Introduction}

Increasing ecological damage produced by biological invasions has begun to occupy a central role in applied ecology and conservation biology. The ecological effects of biological invasions have been the focus of a long series of investigations ranging from population-level manipulation experiments to whole-ecosystem approaches (Simon and Towsend, 2003). Several well-known examples of catastrophic introductions of alien species are now documented in the ecological literature. Classical examples of such introductions include the case of the Nile Perch (Lates niloticus Linnaeus, 1758) in Lake Victoria, East Africa (Kaufman, 1992), and the introduction of the zebra mussel (Dreissena polymorpha Pallas, 1771) in the Laurentian Great Lakes (Ricciardi, 2003). The theory of biological invasions usually predicts that the effects of these introductions are more intense when the invaders occupy higher trophic levels, especially when they are top predators. Several well-documented studies have related the devastating effects of alien top predators in aquatic ecosystems (Simon and Townsend, 2003; Soto et al., 2006; Byström et al., 2007).

The introduction of alien fish species into tropical lakes and reservoirs is accepted as one of the major causes of fish species loss in these ecosystems (Latini and Petrere, 2004). In Brazil, fish introductions are common in most lakes and reservoirs. In most cases, not only have private fishing clubs and associations supported these introductions, but several governmental agencies have also contributed to the spread of several exotic fish species, especially in the hydroelectric reservoir chains in major rivers in southeastern Brazil. The idea was to increase fish production in these new artificial lakes by introducing exotic fishes. Most introductions occurred in the 1960s and 1970s, and consisted of translocations of fish species from the Amazon basin, such as the tucunaré, Cichla ocellaris (Agostinho et al., 2005).

In the present study, the effects of introduction of exotic fish species were investigated in different compartments of the plankton community in one of the most important lake districts of Brazil, the Middle Rio Doce. The lakes studied are located within and near the Rio Doce State Park (Parque Estadual do Rio Doce - PERD). The impacts of these introductions on the local fish fauna are already well described. The presence of the exotic piscivorous tucunaré Cichla $\mathrm{cf}$. ocellaris Bloch and Schneider, 1801 and the red piranha Pygocentrus nattereri Kner, 1858 affected the native fish community, causing the disappearance of some species and a reduction in the abundance of young individuals of others
(Godinho et al., 1994; Latini and Petrere, 2004). These introductions occurred about 30 years ago, and regular monitoring of the fish communities in some of these lakes indicates that these two exotic species are still spreading into new lakes in this area. Most lakes have connections that can be active, especially during extreme rain events (Latini et al., 2005).

This investigation aimed to answer the question as to whether these introductions are affecting other trophic levels in addition to the native fish species of these lakes. Additionally, we analyzed published data and gathered new data showing that the introduction of these two piscivorous fish species contributed to create a zooplankton community structure with the opposite pattern to that predicted by the trophic-cascade hypothesis (sensu Carpenter et al., 1985).

\section{Material and Methods}

\subsection{Study areas}

The lacustrine region of the Rio Doce Valley is the largest lake district in Brazil. This unique system is located in a dammed valley along the middle course of the Rio Doce River, in the state of Minas Gerais, Brazil (CNPq/PELD, 2007). In this area, there are approximately 130 lakes, 42 of them located within the Rio Doce State Park (PERD), which has an area of 36,000 ha and preserves the largest remaining fragment of the Atlantic Forest in the state of Minas Gerais (Latini et al., 2005). The other lakes are located outside the park, where their original catchment basin has been drastically altered by human activities over the last 30 years. Most of the lakes are now surrounded by monocultures of Eucalyptus spp.

In the present study, seven lakes were considered: Dom Helvécio, Carioca, Gambazinho, Jacaré, Amarela, Palmerinha, and Águas Claras. The first three lakes are located inside the PERD. These lakes have different morphometric as well as limnological features (Table 1). These are generally small, shallow lakes (Surface $<5 \mathrm{~km}^{2}$ and $\mathrm{Z}_{\max }<10 \mathrm{~m}$ ). The exception is Lake Dom Helvécio, with a total area of $5.27 \mathrm{~km}^{2}$ and $\mathrm{Z}_{\max }$ of $39.3 \mathrm{~m}$ (Pinto-Coelho et al., in preparation).

\subsection{General methods}

Between August 2004 and September 2005, seven lakes (three lakes in the PERD and four lakes outside it) were studied during the dry (July 2004) and rainy seasons (January 2005). A multi-probe (HORIBA, model $\mathrm{U}-22$ ) was used to measure water temperature, $\mathrm{pH}$, dis- 
solved oxygen concentration, and electrical conductivity at a central point in each lake, covering the entire water column. Further samples were taken with a $2.0 \mathrm{~L}$ Van Dorn sampler for nitrate, ammonium, total phosphorus, and chlorophyll- $a$ determinations as well as for phytoplankton counts. On the day of sampling, two replicate samples of water were filtered through $47 \mathrm{~mm} \mathrm{GF-C}$ Whatman filters. The filtrate was transferred to a clean $500 \mathrm{~mL}$ bottle for inorganic-nitrogen analyses, and the glass-fiber filter was reserved for chlorophyll- $a$ determinations (Lorenzen, 1967). All samples for chemical analyses were stored at $-25{ }^{\circ} \mathrm{C}$ (conventional freezer) until further processing (APHA, 2000).

The phytoplankton samples were collected and preserved in acetic lugol. The density of algal individuals was determined using the inverted-microscope method (Utermöhl, 1958). Integrated triplicate additional samples for taxonomic identification of phytoplankton were also taken with a conical net $(20 \mu \mathrm{m}$ mesh size $)$, preserved in $8 \%$ buffered formalin, and identified according to the classic literature. Zooplankton was sampled in replicates using two conical nets of different mesh sizes: $68 \mu \mathrm{m}$ (microzooplankton) and $200 \mu \mathrm{m}$ (mesozooplankton). Organisms were fixed in $4 \%$ sucrose-formalin solution buffered to $\mathrm{pH} 7.0$, containing the vital stain Rose Bengal.

Fish were sampled in seven different lakes. We used gill nets ( $10 \mathrm{~m}$ long by $1.5 \mathrm{~m}$ wide) with the following mesh sizes: $3,4,5,6,8,10$, and $12 \mathrm{~cm}$. The nets were deployed perpendicularly to the lakeshores at 06:00 PM until the next day, when they were retrieved at 08:00 AM (14 hours of exposure time). The collected specimens were sorted by mesh size and immediately fixed using $10 \%$ formalin. The fixation solution was changed to $70 \%$ ethanol one week later. In the laboratory, all individuals were identified, measured ( $\mathrm{mm}$ ), and weighed (fresh weight, in grams). The results were expressed using the CPUE biomass and numbers of individuals standardized for $100 \mathrm{~m}^{2}$ gill-net surface.

We also compared our data to other sources in the literature and to other data from digital libraries such as the data bank of the long-term ecological program conducted in the region (CNPq/PELD, 2007) and the data bank on freshwater resources of the Rio Doce (FAPEMIG/Rio Doce, 2007).

\subsection{Data analysis}

The quantitative differences in fish community structure between lakes were investigated by co-occurrence analysis. A module of the EcoSim program (Gotelli and Entsminger, 2001) was used. The co-occurrence module tests for non-random patterns of species co-occurrence in a presence-absence matrix. We used the C-Score test,

\begin{tabular}{|ll|l|l|l|l|}
\hline 0 & 1 & 0 \\
1 & 0
\end{tabular}$\quad$ or $\quad$\begin{tabular}{ll}
1 & \\
0 & 1 \\
\hline
\end{tabular}

which measures the tendency for one species to avoid another. A checkerboard unit is any submatrix of the form:

The number of checkerboard units (CU) for each species pair is estimated as:

$\mathrm{CU}=\left(\mathrm{r}_{\mathrm{i}}-\mathrm{S}\right)\left(\mathrm{r}_{\mathrm{j}}-\mathrm{S}\right)$

where is $\mathrm{S}$ is the number of shared sites (sites containing both species), and $r_{i}$ and $r_{j}$ are the row totals for species $\mathrm{i}$ and $\mathrm{j}$. The $\mathrm{C}$-score is the average of all possible checkerboard pairs, calculated for species that occur at least once in the matrix. The larger the $\mathrm{C}$-score, the less the average co-occurrence among species pairs. In a competitively structured community, the C-score should be significantly larger than expected by chance (Gotelli and Entsminger, 2001).

A detrended correspondence analysis (DCA) was used to investigate possible associations between fish fauna and zooplankton. A data matrix of fish (CPUEbiomass) and zooplankton abundance was analyzed together, to identify clusters of lakes of similar structure of zooplankton and fish communities, and to explore any underlying spatial gradient in species composition. Data were $\log$-transformed $(\ln x+1)$ because of the skewed distribution of the original data set.

\section{Results}

In our samplings, all the lakes had very low nitrate concentrations $\left(<10 \mu \mathrm{g} . \mathrm{L}^{-1}\right.$, Table 1$)$, but ammonium exceeded $100 \mu \mathrm{g} . \mathrm{L}^{-1}$ in most lakes, during the dry season. Total phosphorus also reached its maximum seasonal values during the dry season; concentrations of this nutrient varied from 20 to $76 \mu \mathrm{g} . \mathrm{L}^{-1}$ except for the maximum concentration $228 \mu \mathrm{g} . \mathrm{L}^{-1} \mathrm{TP}$ observed in Águas Claras Lake. The catchment area of this lake is completely occupied by a monoculture of Eucalyptus spp. A similar seasonal pattern, with higher values in the dry season, could also be observed for chlorophyll- $a$. The highest concentrations of this algal pigment were found in Carioca (48.6 $\left.\mu \mathrm{g} . \mathrm{L}^{-1}\right)$ and Águas Claras $\left(27.9 \mu \mathrm{g} . \mathrm{L}^{-1}\right)$, respectively (Table 1$)$.

The Rio Doce lakes differ sharply in the abundance and species composition of their phytoplankton communities (Figure 1). The algal species of lakes Carioca, Gambazinho, and Amarela ranged between 43 and 47 taxa; Lake Carioca had the fewest species of all the lakes (Figure 1b). Phytoplankton of lakes Dom Helvécio and Jacaré included more than 60 different taxa of algae.

Higher algal densities were observed for most lakes during the rainy season (Figure 1a). In this season, the total algal densities in lakes Carioca and Águas Claras were much higher than in the other lakes. These two lakes also had the highest chlorophyll- $a$ concentrations (Table 1).

The phytoplankton of some lakes (e.g., Lake Carioca) had not only a low richness of algal species but also a strong dominance of Cyanophyceae (Figure 1c). The fig- 
Table 1. Basic limnological features of the lakes surveyed in the Rio Doce lake district, Minas Gerais, Brazil.

\begin{tabular}{|c|c|c|c|c|c|c|c|c|c|}
\hline Lakes & & $\mathbf{Z}_{\text {sampl. }}$ & $\begin{array}{l}\text { Temp. } \\
\left({ }^{\circ} \mathrm{C}\right)\end{array}$ & $\begin{array}{l}\text { Secchi } \\
\text { (m) }\end{array}$ & $\begin{array}{c}\text { Cond. } \\
\left(\mu \text { S.cm }^{-1}\right)\end{array}$ & $\begin{array}{c}\mathrm{NO}_{3-} \\
\left(\mu{\mathrm{g} . \mathrm{L}^{-1}}^{-1}\right)\end{array}$ & $\begin{array}{c}\mathrm{NH}_{4+} \\
\left(\mu \mathrm{g} . \mathrm{L}^{-1}\right)\end{array}$ & $\begin{array}{c}\mathbf{T P} \\
\left(\mu \mathrm{g} . \mathrm{L}^{-1}\right) \\
\end{array}$ & $\begin{array}{c}\text { Chlorophyll- } a \\
\left(\mu \text { g.L }^{-1}\right)\end{array}$ \\
\hline \multirow{3}{*}{ Dom Helvécio } & Mean & - & 25.7 & - & 45.5 & 2.30 & 254.1 & 18.3 & 5.9 \\
\hline & Max & 30.0 & 32.0 & - & 74.0 & 6.9 & 462.0 & 41.3 & 15.5 \\
\hline & Min & - & 23.0 & 1.50 & 35.0 & 0.0 & 9.0 & 0.0 & 0.6 \\
\hline \multirow[t]{3}{*}{ Carioca } & Mean & - & 26.4 & - & 24.6 & 1.7 & 113.8 & 13.6 & 18.5 \\
\hline & $\operatorname{Max}$ & 10.0 & 31.5 & 2.00 & 13.0 & 0.0 & 268.1 & 22.3 & 48.6 \\
\hline & Min & - & 21.5 & 1.25 & 93.0 & 5.2 & 9.8 & 0.0 & 0.0 \\
\hline \multirow[t]{3}{*}{ Gambazinho } & Mean & - & 27.1 & - & 14.7 & 1.6 & 2.0 & 20.2 & 7.4 \\
\hline & Max & 9.0 & 31.5 & - & 50.0 & 0.0 & 0.0 & 51.6 & 20.8 \\
\hline & Min & - & 22.5 & 1.75 & 13.0 & 4.8 & 5.9 & 0.0 & 0.6 \\
\hline \multirow[t]{3}{*}{ Jacaré } & Mean & - & 26.7 & - & 50.3 & 0.6 & 56.8 & 13.6 & 7.2 \\
\hline & $\operatorname{Max}$ & 9.0 & 32.8 & 2.8 & 217.0 & 1.2 & 105.4 & 25.4 & 21.3 \\
\hline & Min & - & 22.1 & 2.5 & 37.0 & 0.0 & 1.2 & 2.5 & 0.0 \\
\hline \multirow[t]{3}{*}{ Palmerinha } & Mean & - & 26.1 & - & 44.6 & 1.2 & 183.8 & 14.7 & 8.1 \\
\hline & Max & 6.0 & 30.7 & 1.7 & 110.0 & 3.6 & 378.5 & 17.5 & 21.3 \\
\hline & Min & - & 21.9 & 1.3 & 37.0 & 0.0 & 0.0 & 12.4 & 0.4 \\
\hline \multirow[t]{3}{*}{ Águas Claras } & Mean & - & 26.9 & - & 43.7 & 0.8 & 136.6 & 76.4 & 18.3 \\
\hline & Max & 9.0 & 30.9 & 3.0 & 155.0 & 2.4 & 242.0 & 228.2 & 27.9 \\
\hline & Min & - & 22.5 & 2.0 & 38.0 & 0.0 & 0.0 & 0.0 & 0.5 \\
\hline \multirow[t]{3}{*}{ Amarela } & Mean & - & 24.3 & - & 98.6 & 1.27 & 65.6 & 34.8 & 10.1 \\
\hline & Max & 3.0 & 29.3 & 1.0 & 299.0 & 3.80 & 193.6 & 76.3 & 22.9 \\
\hline & Min & - & 19.0 & 0.75 & 53.0 & 0.00 & 0.0 & 1.0 & 1.1 \\
\hline
\end{tabular}

ure also shows that this dominance tended to be more pronounced during the rainy season. Other lakes, such as Gambazinho and Jacaré (dry season) and Águas Claras (rainy season), also had a strong dominance of this group of prokaryotic producers (Figure 1c).

The zooplankton composition of the Rio Doce lakes also was structurally simple (Table 2, Figure 2). The total number of species never exceeded 10 (Table 2). In most lakes, this community was dominated by a simple array of small cyclopoids, cladocerans, and a few rotifers that are commonly found in eutrophic waters in Brazil. The most commonly observed species were Chaoborus spp., Thermocyclops minutus Lowndes, 1934, Bosmina hagmanni Stingelin, 1904, Ceriodaphnia cornuta Sars, 1885, Hexarthra sp., Brachionus calyciflorus Pallas, 1766, and Filinia sp .

The microzooplankton community $(<200 \mu \mathrm{m})$ showed a homogeneous composition in all the lakes. Lakes Carioca, Gambazinho, and Amarela exhibited the highest densities (rainy season) of the smaller fraction (Figure 2a). In most cases, this community was dominated by nauplii of cyclopoid copepods. The mesozooplankton fraction $(>200 \mu \mathrm{m})$ also showed higher densities during the rainy season, except for Lake Jacaré (Figure 2b).

The mesozooplankton in the lakes surrounded by the Tropical Atlantic Forest within the PERD, such as lakes Carioca and Gambazinho, was dominated by the copepod cyclopoid Thermocyclops minutus (Figure 2c).
Larvae of chaoborids were common in the mesozooplankton of most Rio Doce lakes, with higher densities observed in lakes Águas Claras, Jacaré, and Carioca during the dry season of 2004 (Figure 3b). Ostracods were the dominant organisms of this fraction in the lakes situated outside the Rio Doce Park (lakes Águas Claras, Palmeirinha, and Jacaré). Lake Amarela had a unique mesozooplankton structure, dominated by cladocerans. It is interesting to note that Chaoborus larvae were few or absent in this lake (Figure 2c).

It seems that there is an inverse relationship between density of Chaoborus and the number of taxa of cladocerans in the lakes (Figure 3). In these cases, small copepods and rotifers were the most important organisms of the smaller fraction, and cladocerans were rare or even absent.

The pattern of high densities of just a few representatives of zooplankton found for all lakes in this region was not usual only a few years ago (Table 2). We compared our data with some investigations of zooplankton carried out in Rio Doce lakes in the period 1980-2005. This table suggests that a serious species loss has been occurring in most lakes during the past 20 years. The zooplankton community of Lake Carioca, for example, is suffering a steady decrease in species numbers, with the disappearance of all cladocerans from the limnetic zone (Table 2). Moreover, in Lake Dom Helvécio, several species such as the calanoids Argyrodiaptomus furcatus Sars, 1901 and Scolodiaptomus corderoi Wright, 1936, that were 
Dry season - 2004
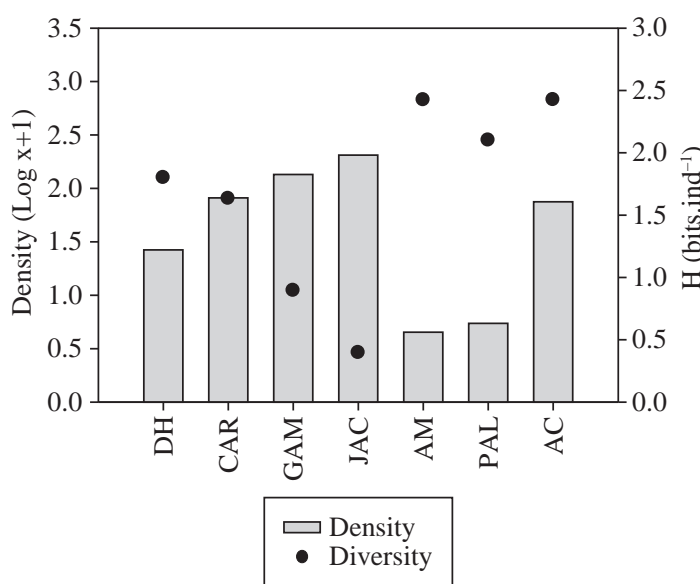

Wet season - 2005

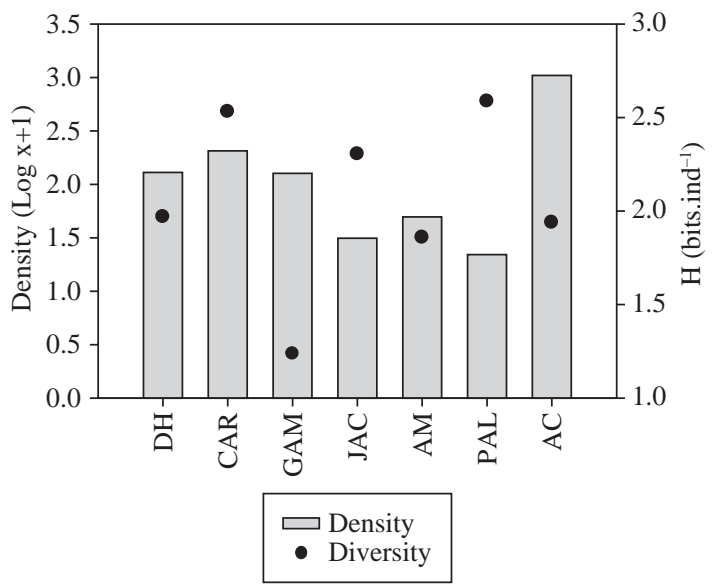

(b)

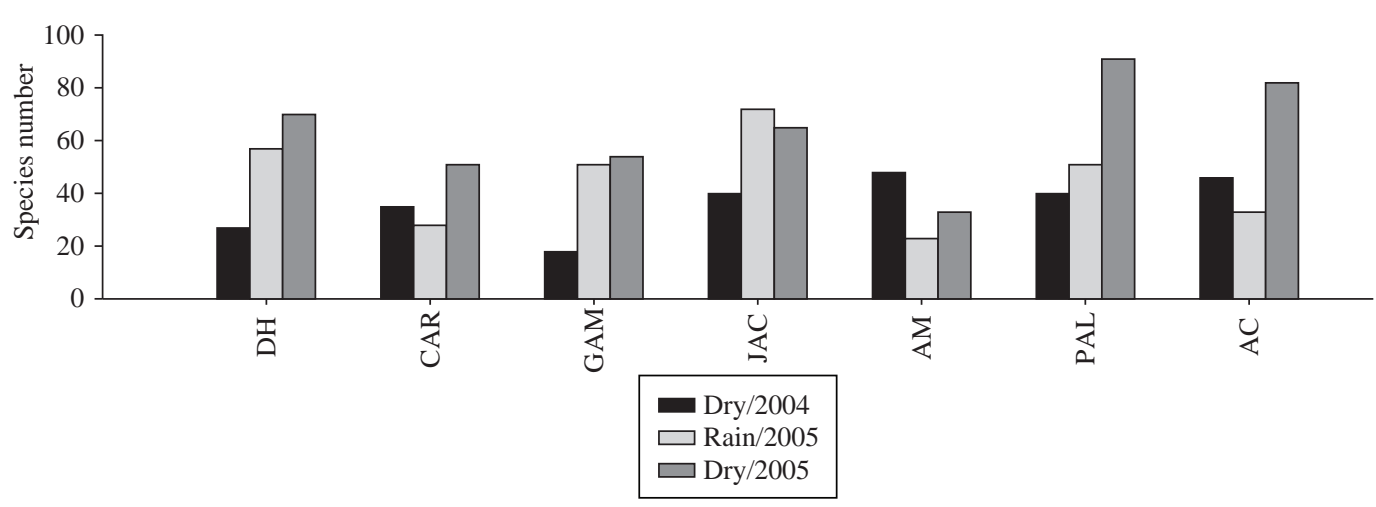

(a)
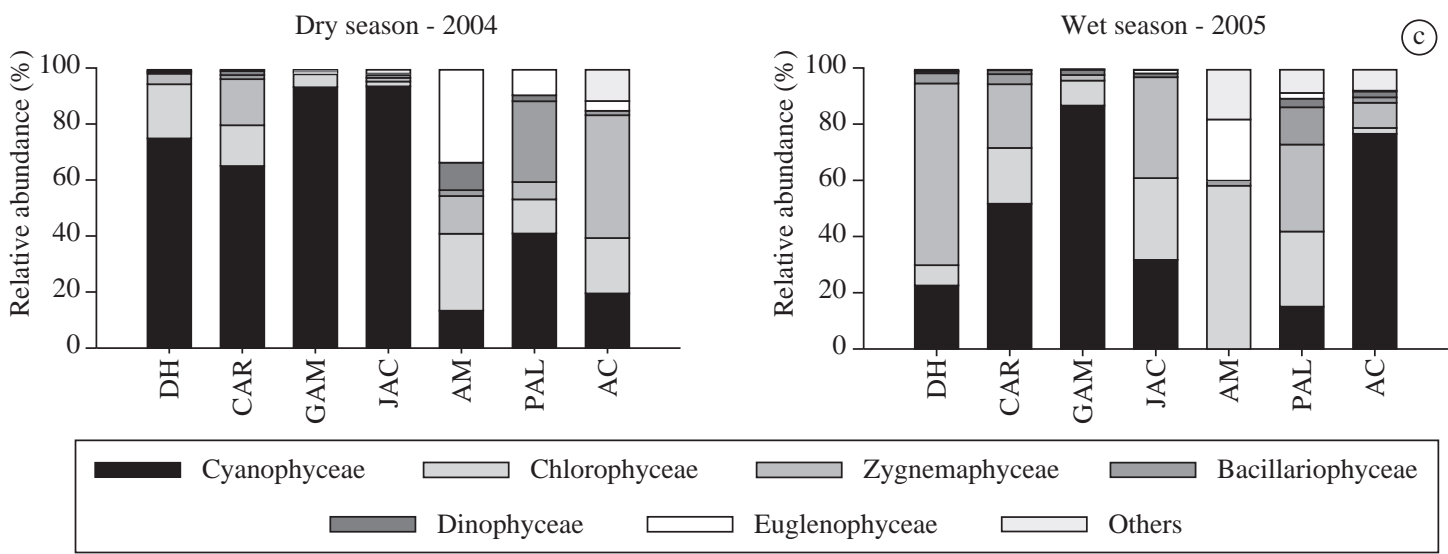

Figure 1. Phytoplankton community of seven lakes of the Middle Rio Doce, Minas Gerais. a) Mean density and Shannon diversity of phytoplankton; b) Species richness of phytoplankton in both periods of the seasonal cycle; and c) Relative abundance of phytoplankton community. All data refer to different seasons (dry season: July 2004 and wet season: January, 2005).

often observed, are now completely absent. Other larger copepods such as Mesocyclops longisetus Thiébaud, 1912 and Microcyclops varicans Sars, 1863 and the cladocerans Bosmina coregoni Baird, 1857 and Moina minuta Hansen, 1899 also became extinct in this lake.

As expected from previous studies, we did not find any exotic fish species in Lake Gambazinho (Figure 4a).
The cumulative biomass of the fish community (CPUE b) in the lakes varied from 3.7 to $8.2 \mathrm{~kg}$ (Figure $4 \mathrm{~b}$ ). The highest biomass values (CPUEb $\geq 3.9 \mathrm{~kg}$ ) were found for the exotic red piranha in lakes Águas Claras, Carioca, and Dom Helvécio (Figure 4b). The exotic Cichla cf. ocellaris is well known for avoiding gill nets (Godinho and Formagio, 1992), thus the biomass of this 
Table 2. Species richness of zooplankton in some lakes of the Rio Doce lake district.

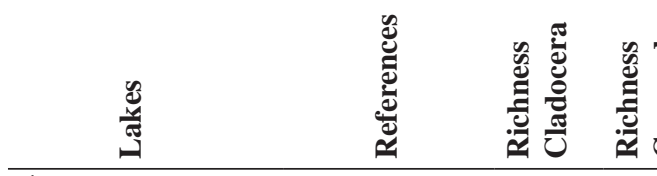

Águas Claras

$1985^{2}$

$2001^{6}$

$2002^{5}$

This study

(2004-05)

Amarela

$\begin{array}{lll}1980^{8} & 3 & 2 \\ 2001^{6} & 4 & 4 \\ \text { This study } & 4 & 5 \\ (2004-05) & & \end{array}$

Carioca

$\begin{array}{lcc}1980^{8} & 4 & 2 \\ 1980^{7} & 11 & 3 \\ 2001^{6} & 1 & 3 \\ 2002^{4} & 7 & 3 \\ 2003^{9} & 2 & 2 \\ 2004^{10} & 1 & 2 \\ 2005^{11} & 1 & 1 \\ \text { This study } & 0 & 1 \\ \text { (2004-05) } & & \end{array}$

Dom Helvécio

$\begin{array}{lll}1980^{7} & 8 & 7 \\ 1980^{8} & 7 & 6 \\ 1983^{1} & 5 & 5 \\ 1985^{3} & 5 & 5 \\ 2002^{4} & 5 & 4 \\ 2003^{9} & 5 & 3 \\ 2004^{10} & 5 & 2 \\ 2005^{11} & 5 & 2 \\ \text { This study } & 4 & 2 \\ \text { (2004-05) } & & \end{array}$

Gambazinho

\begin{tabular}{lll}
$2002^{4}$ & 4 & 3 \\
$2003^{9}$ & 3 & 3 \\
$2004^{10}$ & 4 & 3 \\
$2005^{11}$ & 3 & 3 \\
This study & 3 & 2 \\
$(2004-05)$ & & \\
$1985^{2}$ & 3 & 2 \\
$2003^{9}$ & 6 & 2 \\
\hline
\end{tabular}

2005
This study
(2004-05)
1985
2002
This study
(2004-05)

species was probably underestimated. The comparison of relative fish abundance (CPUEn) among all the lakes also showed the great quantitative importance of exotic fishes in most lakes (Figure 4c). The native fish species that still have relative significance were Hoplias malabaricus Bloch, 1794, Oligosarcus solitarius Menezes, 1987, and Hoplosternum littorale Hancock, 1828.

The Checkerboard score of fish assemblage was higher than expected by chance (Observed in$\operatorname{dex}=1.76$; mean of simulated indices $=1.57 ; \mathrm{p}$ observed $\geq$ expected $=0.0214,10,000$ permutations). Pygocentrus nattereri and Hoplosternum littorale exhibited the most antagonistic behavior (Table 3). The impact of exotic fish on native fish and zooplankton populations is shown by DCA analysis (Figure 5). Lake Gambazinho, without exotic fish, formed a distinct group with small native fishes such as Astronotus ocellatus Agassiz and Spix and Agassiz, 1831, Astyanax bimaculatus Linnaeus, 1758, and Oligosarcus solitarius, Ceriodaphnia, calanoid copepodites, and Calanoida. Another group was formed by Chaoborus larvae, associated with the exotic fishes (Cichla ocellaris and Pygocentrus nattereri) that prevail in lakes Águas Claras and Carioca (Figure 5).

\section{Discussion}

The Phytoplankton of the most Rio Doce studied lakes is typically a low diverse community with strong dominance of Cyanophyceae. The zooplankton community is also relatively simple. The total number of observed copepod and cladoceran species always remained below 10 . There was a clear inverse relationship between Chaoborus abundance and species richness of cladocerans. We also 

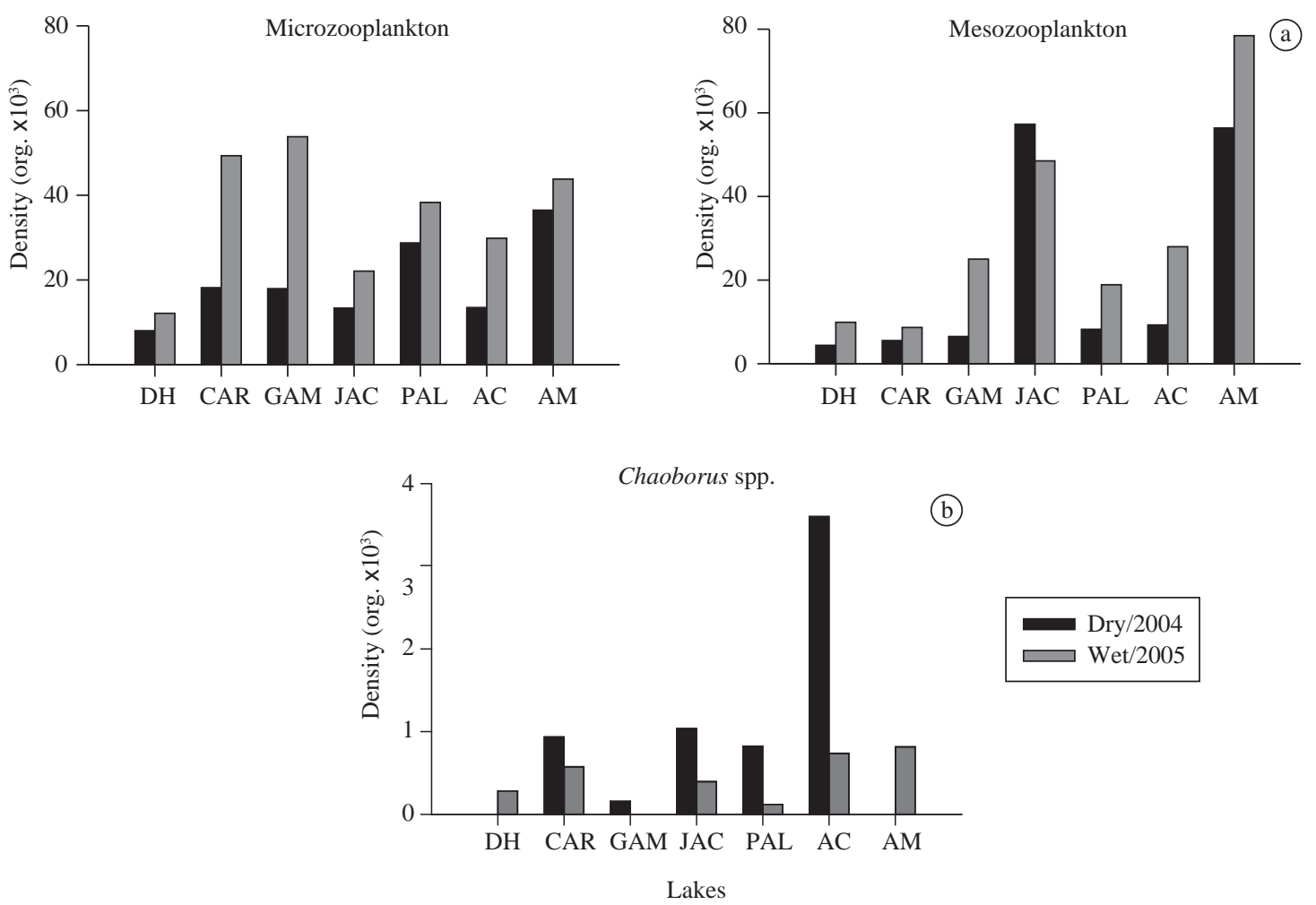
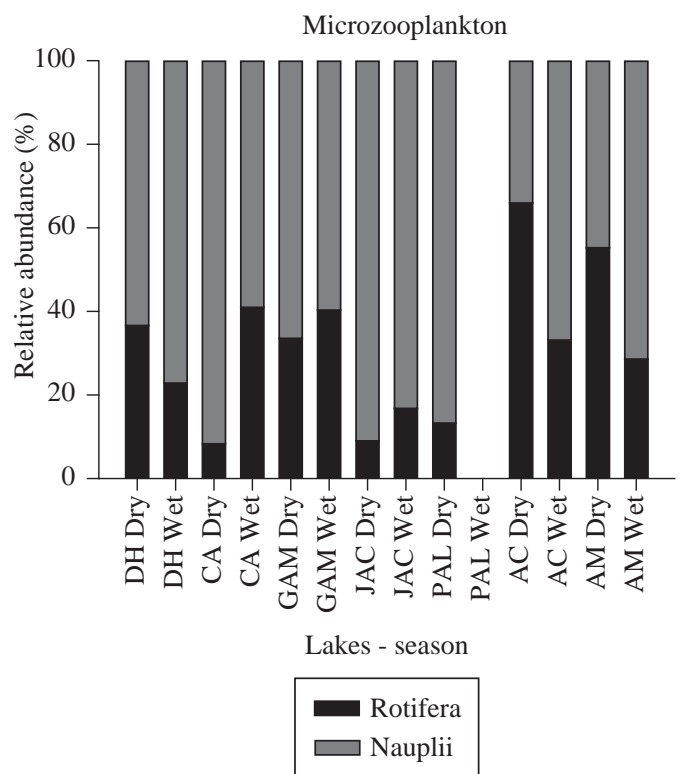

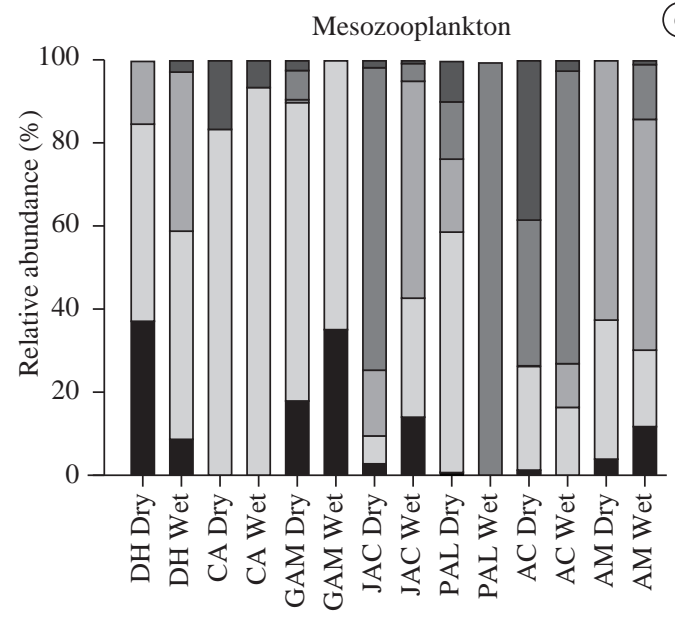

Lakes - season

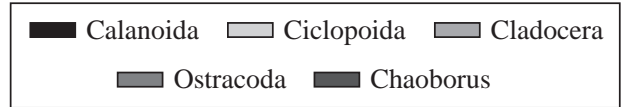

Figure 2. Zooplankton community in seven lakes of the Middle Rio Doce, Minas Gerais. a) Abundance of two size fractions of zooplankton: meso- and microzooplankton; b) Abundance of Chaoborus in the lakes; and c) Relative abundance of size fractions of zooplankton. All data refer to different seasons (dry season: July 2004 and wet season: January, 2005).

confirmed a reduced species richness of fish communities in lakes of the Middle Rio Doce, with a strong dominance of biomass of two alien piscivorous fish species.

The literature shows, however, that these communities have never been rich in species. In the early 1980s, four representative lakes of this region (Dom Helvécio, Jacaré, Carioca, and Amarela) had a total fish richness of 25 (Godinho and Vieira, 1998). However, the number of fish species today is reduced to 3-6 in the same lakes. Most authors agree that this reduction is a direct result of 
Table 3. Number of checkerboard units calculated for each species pair. (E) represents exotic species.

\begin{tabular}{|c|c|c|c|c|c|c|c|c|c|c|c|c|c|c|}
\hline Species & 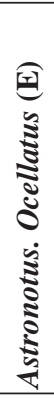 & 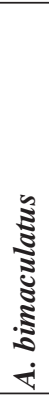 & 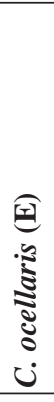 & 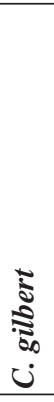 & 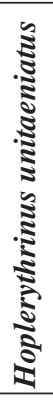 & 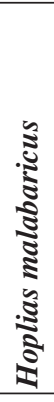 & 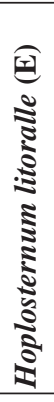 & 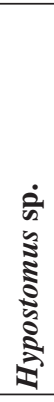 & 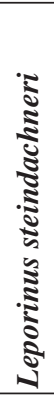 & 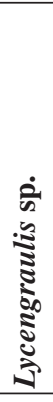 & 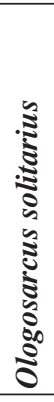 & 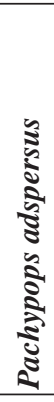 & 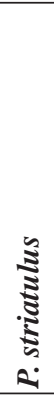 & 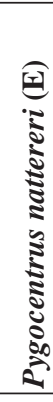 \\
\hline Astronotus ocellatus (E) & - & 0 & 2 & 1 & 1 & 0 & 0 & 1 & 1 & 1 & 2 & 2 & 0 & 0 \\
\hline Astyanax bimaculatus & - & - & 6 & 0 & 3 & 0 & 6 & 0 & 0 & 3 & 0 & 2 & 2 & 10 \\
\hline Cichla cf. ocellaris (E) & - & - & - & 2 & 0 & 0 & 3 & 2 & 2 & 2 & 4 & 4 & 3 & 0 \\
\hline $\begin{array}{l}\text { Cyphocarax gilbert } \\
\text { Quoy and Gaimard, } 1824\end{array}$ & - & - & - & - & 1 & 0 & 4 & 0 & 0 & 1 & 0 & 0 & 0 & 6 \\
\hline $\begin{array}{l}\text { Hoplerythrinus unitaeniatus } \\
\text { Spix and Agassiz, } 1829\end{array}$ & - & - & - & - & - & 0 & 0 & 1 & 1 & 1 & 2 & 2 & 0 & 0 \\
\hline Hoplias malabaricus & - & - & - & - & - & - & 0 & 0 & 0 & 0 & 0 & 0 & 0 & 0 \\
\hline Hoplosternum litoralle $(\mathrm{E})$ & - & - & - & - & - & - & - & 4 & 4 & 4 & 8 & 8 & 1 & 0 \\
\hline Hypostomus sp. & - & - & - & - & - & - & - & - & 0 & 1 & 0 & 0 & 0 & 6 \\
\hline $\begin{array}{l}\text { Leporinus steindachneri } \\
\text { Eigenmann in Eigenmann and } \\
\text { Ogle, } 1907\end{array}$ & - & - & - & - & - & - & - & - & - & 1 & 0 & 0 & 0 & 6 \\
\hline Lycengraulis sp. & - & - & - & - & - & - & - & - & - & - & 2 & 0 & 4 & 0 \\
\hline Oligosarcus solitarius & - & - & - & - & - & - & - & - & - & - & - & 1 & 3 & 12 \\
\hline $\begin{array}{l}\text { Pachypops adspersus } \\
\text { Steindachner, } 1879\end{array}$ & - & - & - & - & - & - & - & - & - & - & - & - & 3 & 5 \\
\hline $\begin{array}{l}\text { Parauchenipterus striatulus } \\
\text { Steindachner, } 1879\end{array}$ & - & - & - & - & - & - & - & - & - & - & - & - & - & 3 \\
\hline
\end{tabular}

Cladocera richness $=5.063-(0.00422 *$ Density Chaoborus $)$

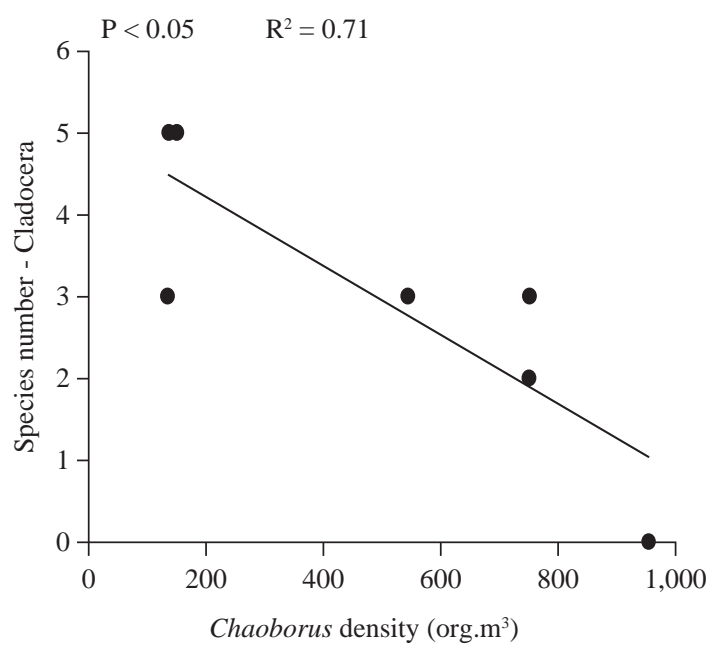

Figure 3. Scatter plot and linear regression between density of Chaoborus (x-axis) larval instars and number of taxa of cladocerans (y-axis) in the dry season of 2005. the introduction of the two piscivorous fishes Cichla $\mathrm{cf}$. ocellaris and Pygocentrus nattereri (Godinho et al., 1994, Latini and Petrere, 2004, Latini et al., 2005). Looking at the high $\mathrm{C}$-score index found in this study, we have clear evidence of the antagonistic checkerboard pattern between the exotic piscivorous Pygocentrus nattereri and several native fish species (Table 3 ).

We propose the hypothesis that the changes in fish community in the lakes of the Middle Rio Doce are inducing further changes at lower trophic levels. However, this chain of events linked to the introduction of piscivorous fish in these lakes is contradictory to the predictions of the trophic-cascade hypothesis (Carpenter et al., 1985): when piscivores are abundant and planktivorous fish are scarce, zooplankton biomass may be high and dominated by large species, resulting in higher grazing rates on phytoplankton. This hypothesis, with some minor modifications, is still the ecological basis for biomanipulation of most temperate systems (De Melo et al., 1992; Jeppesen et al., 2007).

In the lakes of the Middle Rio Doce, the introductions of piscivorous fish resulted in an increase in the 

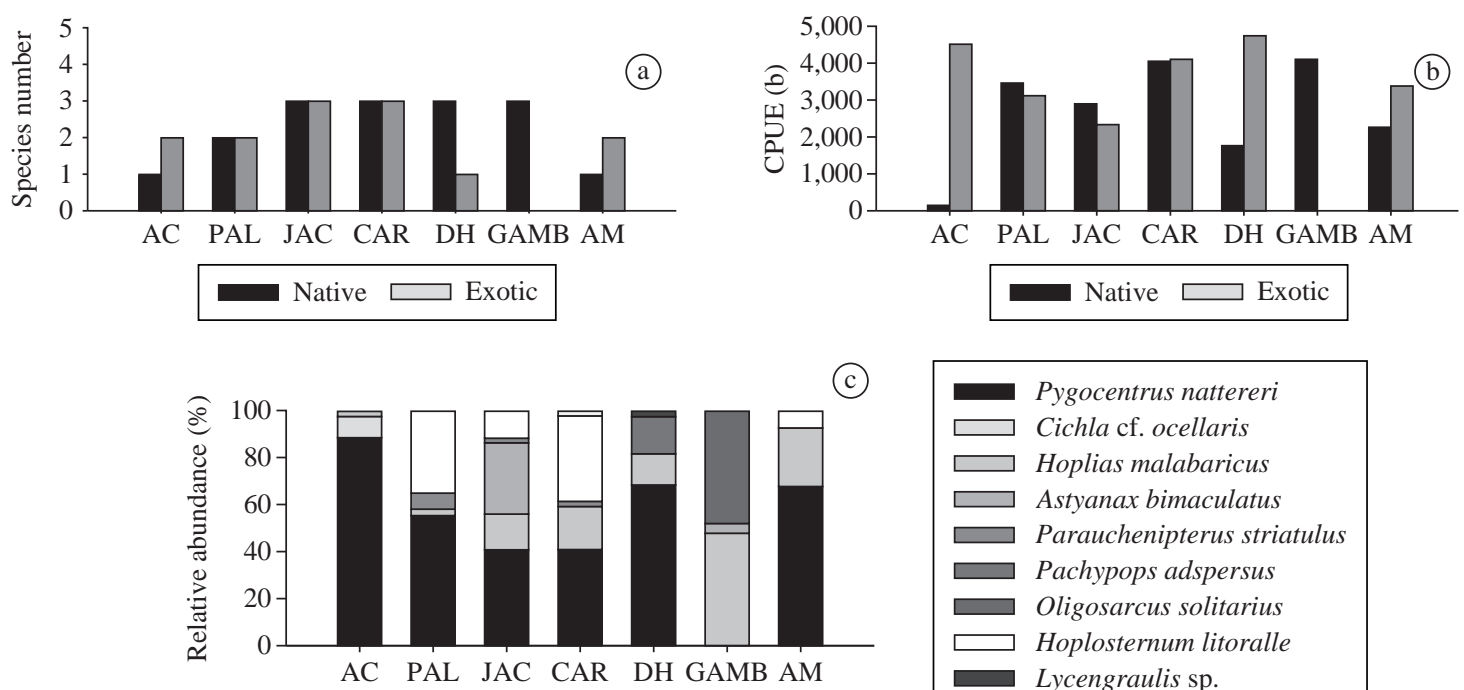

(c)

Lakes

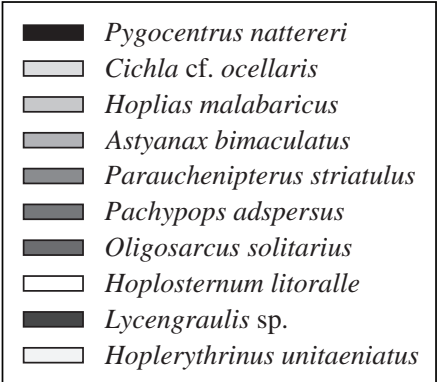

Figure 4. Fish community in seven lakes of the Rio Doce lake district. a) Native and alien fish species; b): Biomass - CPUE $\mathrm{b}$ (wet weight, in grams); and c) Relative abundance in numbers (CPUE- n) of fish catches.

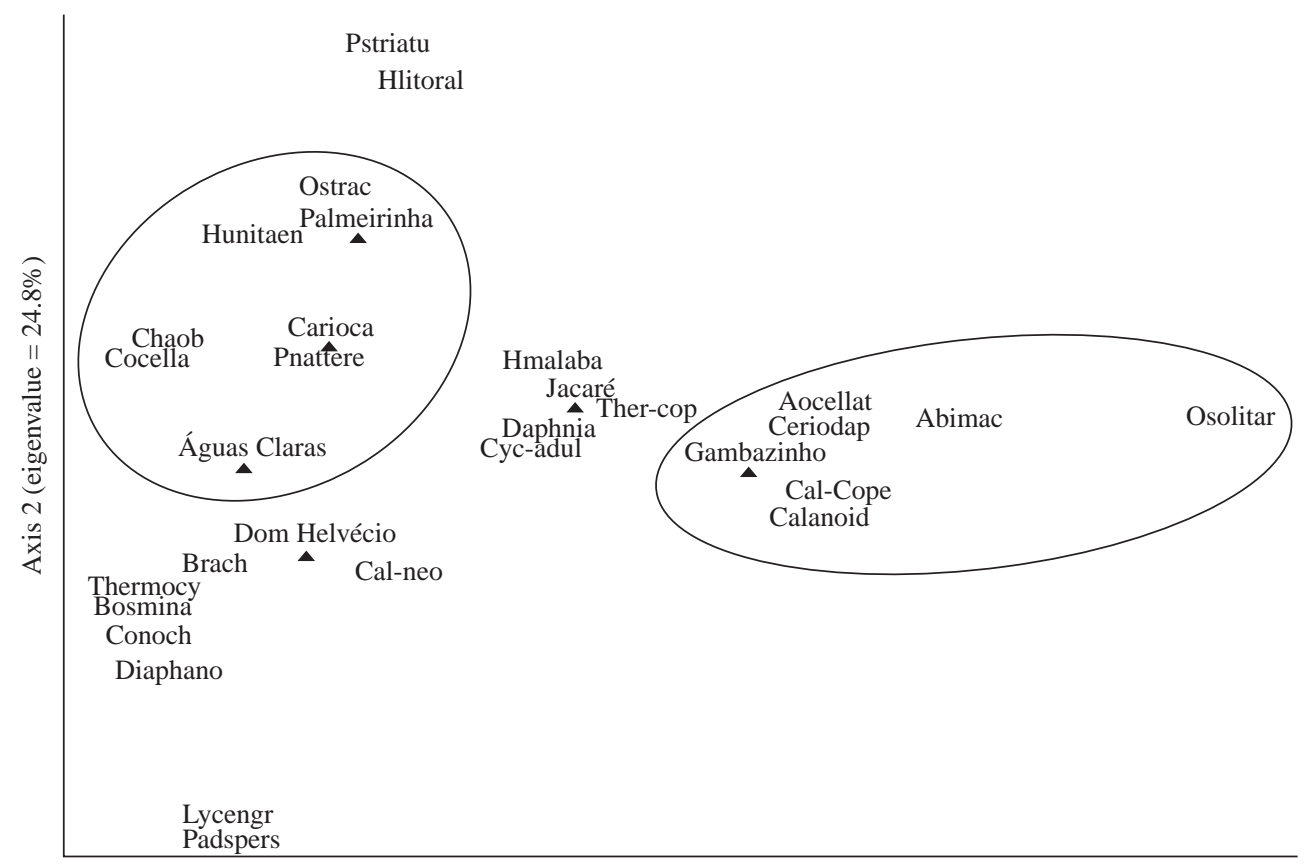

Axis 1 (eigenvalue $=33.6 \%)$

Figure 5. DCA ordination biplot diagram of fish (bold) and zooplankton community. Log-transformed data (ln $x+1)$ include all species, including rare species (only one occurrence). Codes: a) Lake names = Águas Claras, Carioca, Dom Helvécio, Gambazinho, Jacaré, and Palmeirinha (triangles). There was no fish sampling in Lake Amarela. b) Fish species (bold) Abimac = Astyanax bimaculatus $($ native $)$, Aocellat $=$ Astronotus ocellatus $($ exotic $), \quad$ Cocella $=$ Cichla cf. ocellaris $($ exotic), Hmalaba = Hoplias malabaricus (native), Hlitoral = Hoplosternum littorale $($ exotic), Hunitaen = Hoplerythrinus unitaeniatus $($ native $)$, Lycengr $=$ Lycengraulis sp., (native), Osolitar = Oligosarcus solitarius $($ native $)$, Pnatere = Pygocentrus nattereri $($ exotic), Padispers = Pachypops adspersus $($ native), Pstriatu = Parauchenipterus striatulus $($ native $)$. c) Zooplankton organisms - Bosmina = Bosmina sp., Brach = Brachionus sp., Ceriodap = Ceriodaphnia sp., Chaob = Chaoborus sp., Conoch $=$ Conochilus $\mathrm{sp} .$, Clad neo $=$ neonates of Cladocera, Cyc-adult $=$ males + females of Cyclopoida, Daphnia = Daphnia $\mathrm{sp}$. , Diaphano = Diaphanosoma sp., Ostrac = Ostracoda, Ther-cop = Thermocyclops sp. (copepodites). The two groups (clusters) indicate lakes with and without exotic fish species and the most important zooplankton groups that prevail in each case. 
abundance of invertebrate predators (Chaoborus). These organisms replaced the planktivorous fish as major consumers of herbivorous zooplankton. The increase in density of this invertebrate predator was probably the result of an "ecological release" caused by the reduction of fish predation. Ecological release is a well-known phenomenon (Cox and Ricklefs, 1977). It occurs when there is a density increase resulting from the enlargement of the ecological niche of a species, resulting in decreases in competition or predation pressure (Losos and Queiroz, 1997).

Innumerable studies have shown that small cladocerans, rotifers, juvenile copepods (copepodites), and nauplii often dominate the zooplankton communities in tropical lakes (e.g., Lewis, 2000; Pinto-Coelho et al., 2005). Chaoborus larvae normally coexist in this environment and are controlled by fish predation. Originally, the structure of the zooplankton community of most lakes in the Middle Rio Doce did not differ from this general pattern, with a general low diversity of microcrustaceans (copepods and cladocerans) and a numerical dominance of rotifers. However, the introduction of strictly piscivorous fishes in some lakes is possibly linked to a large species erosion and diversity decay of microcrustaceans. Today, it is common to find lakes in the Rio Doce Valley where the zooplankton fauna is reduced to only one species of copepod (Thermocyclops minutus) with a complete absence of limnetic cladocerans (e.g. Lake Carioca).

The major effects associated with the introduction of alien fish species on the ecosystem functioning of the Middle Rio Doce lakes are summarized in Figure 6. The introduction of the two piscivorous fishes caused - at first - a sharp decrease in fish species richness, with almost all the planktivorous fish becoming locally extinct. The next effect was the uncontrolled development of Chaoborus populations. This effect can be seen in lakes Carioca,
Palmeirinha, and Águas Claras. These lakes have high proportions of exotic fishes and relatively high densities of chaoborids in the mesozooplankton (Figure 5), and in our samples exhibited the highest seasonal values of chlorophyll- $a$ of phytoplankton. The increase in density of the invertebrate predators caused a sharp reduction of cladocerans. Under these circumstances, rotifers, cyclopoid copepodites, and nauplii, associated with other temporary limnetic organisms such as ostracods, dominated the smaller zooplankton fraction. Furthermore, these lakes also show a clear biomass accumulation of primary producers in the lakes, usually represented by cyanobacteria. These results are contrary to the predictions supported by the trophic cascade hypothesis (op. cit.), because the increase of piscivory in the Rio Doce lakes actually led to a reduction of grazing pressure on phytoplankton by zooplankton.

The phenomenon of ecological release affecting chaoborid larvae can be seen indirectly by considering some behavioral characteristics of the chaoborids from Rio Doce lakes. The behavior of vertical migration of zooplankton is widely accepted as a mechanism of evading predators in the water column (Gliwicz, 1986). Usually, the zooplankton mostly ascends into the epilimnion at night and migrates down into the colder, darker, and oxygen-poor waters in the deeper layers at dawn, to avoid predation by visually oriented planktivorous fish. A strong evidence of the lack of vertebrate predation on zooplankton in Rio Doce lakes, especially on chaoborid instars, is the total absence of vertical migration in the populations of Chaoboridae in lakes with exotic fish species, such as Lake Carioca (Bezerra-Neto, 2007).

Some studies have demonstrated that in lakes where an extreme enhancement of piscivory occurred ("overbiomanipulation"), an increase in the abundance of large invertebrate predators can occur, which then exerts
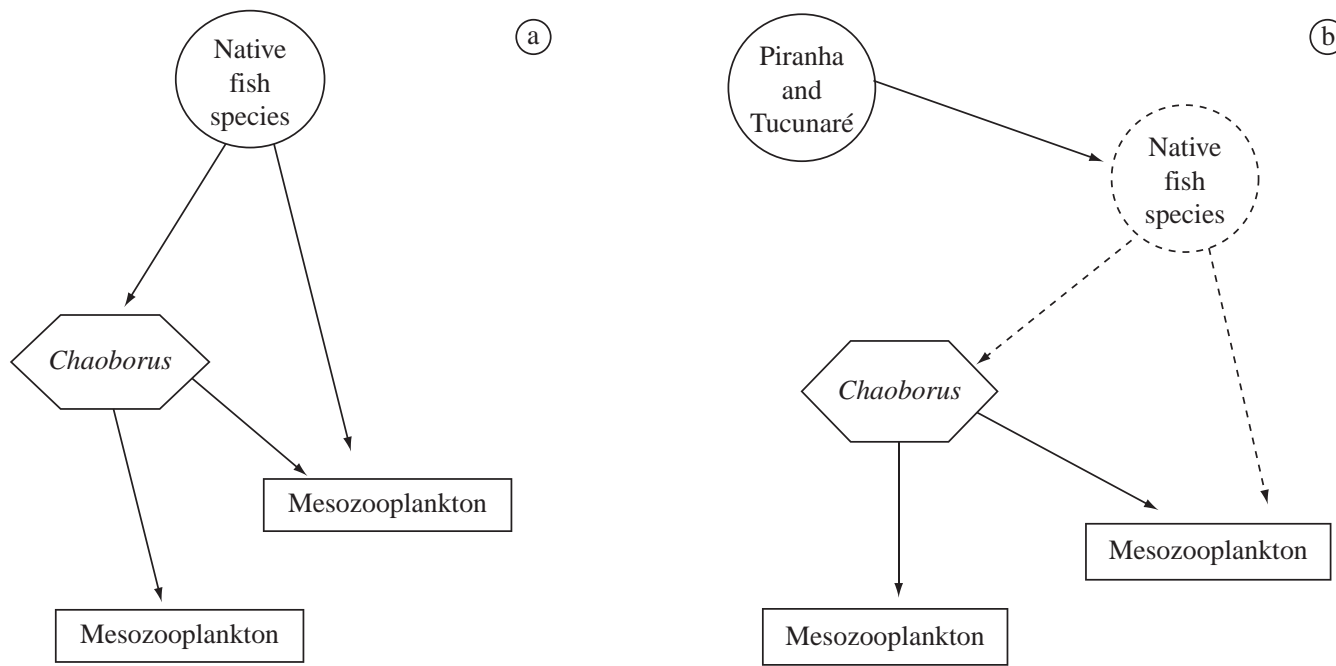

Figure 6. Schematic food web of lakes of the Middle Rio Doce before a) and after b) the introduction of exotic fish species. 
strong predation pressure on herbivorous zooplankton (Wissel et al., 2000; Bendorf et al., 2000). However, the effects of reduction of fish predation on Chaoborus larvae become more acute in tropical lakes because: (1) in these environments, the chaoborids are the only largebodied zooplankton invertebrate predators, because other crustacean predators such as Mysis, Bythotrephes, and Leptodora, common in temperate lakes, are absent (Fernando, 1994); (2) chaoborids reproduce throughout the year and their life cycles last approximately 4060 days, in contrast with 1-2 years in temperate environments (Bezerra-Neto and Pinto-Coelho, 2002); and (3) bottom-water anoxia is more common in tropical lakes, which may provide chaoborids with a refuge from fish predation (Lewis, 2000).

This study demonstrated the effects of the piscivorous fish invaders on the entire trophic web in some of the most important Middle Rio Doce lakes. These impacts extended not only to the crustacean zooplankton but also affected the primary producers. As suggested by the results, future invasions of Pigocentrus natererii and Cichla cf. ocellaris will have strong negative effects on fish communities by decreasing the richness of native fish species and by changing the configuration of entire ecosystems through top-down cascading effects on the lower trophic levels. Nowadays, only three lakes within the park reserve do not host alien fish species - Gambazinho, Azul, and Lagoinha. Outside the reserve, the situation is somewhat better: 13 lakes have their original fish fauna untouched by human activities (Latini et al., 2005).

The recent ecological changes observed in lakes of the Middle Rio Doce provide strong evidence of cumulative and synergetic human factors related to the explosive and unplanned increase in human occupation in the watershed of one of the most important river basins of southeastern Brazil. One of the major tasks of ecologists working on impacted areas is attempting not only to identify but also to understand the major ecological impacts of different human activities on the existing biota, especially if these impacts are causing species extinctions. Thus, these findings reinforce the urgency of improving the strategies of management and conservation of freshwater resources in the region.

Acknowledgements - We would like to thank Dr. Liliana Rodrigues and Dr. Janet W. Reid for checking taxonomic determinations and the improvement of the English writing. We also thank the FAPEMIG (No. 1541/03) and the Long-Term Ecological Research Program (PELD - CNPq) for supporting this study.

\section{References}

APHA - AMERICAN PUBLIC HEALTH ASSOCIATION. 2000. Standard Methods for the Examination of Water and Wastewater. 19 ed. New York.
AGOSTINHO, AA., THOMAZ, SM. and GOMES, LC., 2005. Conservation of the biodiversity of Brazil's inland waters. Conserv Biol, vol. 19, no. 3, p. 646-652.

BENNDORF, J., WISSEL, B., SELL, AF., HORNIG, U., RITTER, P. and BÖING, W., 2000. Food web manipulation by extreme enhancement of piscivory: an invertebrate predator compensates for the effects of planktivorous fish on a plankton community. Limnologica, vol. 30, no. 3, p. 235-245.

BEZERRA-NETO, JF., 2007. A predação e a comunidade planctônica: efeitos diretos e indiretos em corpos aquáticos tropicais. Belo Horizonte: Universidade Federal de Minas Gerais - UFMG. 144 p. [Ph.D. Thesis].

BEZERRA NETO, JF., PINTO-COELHO, RM., 2002. Population dynamics and secondary production of Chaoborus brasiliensis (Diptera - Chaoboridae) in a small tropical reservoir: Lagoa do Nado, Belo Horizonte (MG). Acta Limnol. Brasil., vol. 14, no.3, p. 145-161.

BRANDÃO, ECL., BRAZ, SA., BRITO, SL., MENENDEZ, RM. and MAIA-BARBOSA, PM., 2002. Flutuação mensal do zooplâncton dos lagos Carioca, Dom Helvécio e Gambazinho (Parque Estadual do Rio Doce). In BARBOSA, FAR. (Coord.). Relatório Técnico-Científico das atividades de dezembro de 2001 a agosto 2002 - Pesquisas Ecológicas de Longa Duração $(P E L D-C N P q)$ - Sitio 04. Available from: http://www.icb. ufmg.br/peld/ufmg/

BRITO, SL., VALADARES, CF., MENENDEZ, RM. and MAIA-BARBOSA, PM., 2002. Estrutura da comunidade zooplanctônica em três lagoas do entorno do Parque Estadual do Rio Doce (MG). In: BARBOSA, FAR. (Coord.). Relatório Técnico-Científico das atividades de dezembro de 2001 a agosto 2002 - Pesquisas Ecológicas de Longa Duração (PELD-CNPq) - Sitio 04. Available from: http://www.icb.ufmg.br/peld/ufmg/

BYSTRÖM, P., KARLSSON, J., NILSSON, P., VAN KOOTEN, T., ASK, J. and OLOFSSON, F., 2007. Substitution of top predators: effects of pike invasion in a subarctic lake. Fresh. Biol., vol. 52, no. 7, p. 1271-1280.

CARPENTER, SR., KITCHELL, JE. and HODGSON, JR., 1985. Cascading trophic interactions and lake productivity. BioScience, vol. 35, no. 10, p. 634-639.

CNPQ / PELD - SITE 4, 2007. Mata Atlântica e Sistema Lacustre do Médio Rio Doce. Pesquisas Ecológicas de Longa Duração - Sítio No 4. Available from: http://www.icb.ufmg.br/ peld/ufmg.

COX, GW. and RICKLEFS, RE., 1977. Species diversity, ecological release, and community structuring in Caribbean land bird faunas. Oikos, vol. 29, no.1, p. 60-66.

DE MELO, R., FRANCE, R. and MCQUEEN, DJ., 1992. Biomanipulation: Hit or Myth? Limnol. Oceanogr., vol. 37, no.1, p. 192-207

FAPEMIG/Rio Doce, 2007. Biblioteca digital dos recursos hídricos do médio rio Doce. Minas Gerais: Fundação de Amparo à Pesquisa de Minas Gerais, FAPEMIG. Available from: http:// ecologia.icb.ufmg.br/ rpcoelho/RioDoce/website/index.htm.

FERNANDO, CH. 1994. Zooplankton, fish and fisheries in tropical freshwaters. Hydrobiologia, vol. 272, no. 1-3, p. 105-123. 
GLIWICZ, MZ., 1986. Predation and the evolution of vertical migration in zooplankton. Nature, vol. 320, no. 6064, p. 746-748.

GODINHO, AL., FONSECA, MT. and ARAÚJO, ML., 1994. The ecology of predator fish introductions: the case of rio Doce valley lakes. In PINTO-COELHO, RM., GIANI, A. and VON SPERLING, E. (Eds.). Ecology and human impact on lakes and reservoirs in Minas Gerais with special reference to future development and management strategies. Belo Horizonte: SEGRAC. p. 77-83.

GODINHO, AL. and FORMAGIO, PS., 1992. Efeitos da introdução de Cichla ocellaris e Pygocentrus sp. sobre a comunidade de peixes da Lagoa Dom Helvécio. Encontro Anual de Aqüicultura de Minas Gerais, vol. 10, p. 93-102.

GODINHO, AL. and VIEIRA, F., 1998. Ictiofauna. In COSTA, C. (Ed.). Biodiversidade em Minas Gerais: Um atlas para sua conservação. Belo Horizonte: Fundação Biodiversitas. p. $44-46$

GOTELLI, NJ. and ENTSMINGER, GL., 2001. EcoSim: Null models software for ecology. Version 7.0. Acquired Intelligence Inc. \& Kesey-Bear. Available from: http://homepages.together. net/ gentsmin/ecosim.htm.

GUIMARÃES, AS., AOKI, A., VALADARES, CF., MELLO, NAST., PEIXOTO, RS., MENENDEZ, RM., BRAZ, AS., BRITO, SL. and MAIA-BARBOSA, PM., 2005. Comunidade zooplanctônica de sete lagos do Parque Estadual do rio Doce e entorno. In BARBOSA, FAR. (Coord.). Relatório TécnicoCientífico das atividades de janeiro a dezembro 2005 Pesquisas Ecológicas de Longa Duração (PELD-CNPq) - Sitio 04. Available from: http://www.icb.ufmg.br/peld/ufmg/

JEPPESEN, E., MEERHOFF, M., JACOBSEN, BA., HANSEN, RS., SØNDERGAARD, M., JENSEN, JP., LAURIDSEN, TL., MAZZEO, N. and BRANCO, CWC., 2007. Restoration of shallow lakes by nutrient control and biomanipulation - the successful strategy varies with lake size and climate. Hydrobiologia, vol. 581, no. 1, p. 269-285.

KAUFMAN, L., 1992. Catastrophic change in species-rich freshwater ecosystems: the lessons of Lake Victoria. Bioscience, vol. 42 , no. 11 , p. 846-858.

LATINI, AO., PEREIRA, TL., LATINI, RO., GIACOMINI, HC., LIMA JÚNIOR, DP., OPORTO, LT. and ESPÍRITOSANTO, HMV., 2005. Distribuição e efeitos de peixes exóticos sobre a ictiofauna nativa dos lagos do Médio Rio Doce, MG, Brasil. In ROCHA, O., ESPÍNDOLA, E., VERANI, N., VERANI, JR., RIETZLER, AC. (Eds.). Espécies invasoras em águas doces: estudos de caso e propostas de manejo. 1 ed. São Carlos, SP: Gráfica Expressa. p. 99-129.

LATINI, AO. and PETRERE, M., 2004. Reduction of native fish fauna by alien species: an example from Brazilian freshwater tropical lakes. Fish. Manag. Ecol., vol. 11, no. 2, p. 71-79.

LEWIS, W., 2000. Basis for the protection and management of tropical lakes. Lakes Reserv.: Res. Manage., vol. 5, no. 1, p. $35-48$

LORENZEN, CJ., 1967. Determination of chlorophyll and pheopigments: spectrophotometric equations. Limnol. Oceanogr., vol. 12, no. 2, p. 343-346.

LOSOS, JB. and QUEIROZ, K., 1997. Evolutionary consequences of ecological release in Caribbean Anolis lizards. Biol. J. Linn. Soc., vol. 61, no. 4, p. 459-483.
MAIA-BARBOSA, PM., MENENDEZ, RM., VALADARES, CF., BRANDÃO, ECL., BRAZ, AS. and BRITO, SL., 2003. Composição da comunidade zooplanctônica de rios e lagos do trecho médio da bacia do Rio Doce-MG. In BARBOSA, FAR. (Coord.). Relatório Técnico-Científico das atividades de agosto 2002 a dezembro - Pesquisas Ecológicas de Longa Duração (PELD - CNPq) - Sitio 04. Available from: http://www.icb. ufmg.br/peld/ufmg/

MAIA-BARBOSA, PM., MENENDEZ, RM., VALADARES, CF., BRANDÃO, ECL., BRAZ, AS., BRITO, SL., AOKI, A. and MELLO, NAST., 2004. Composição da comunidade zooplanctônica de rios e lagos do trecho médio da Bacia do Rio Doce-MG. In: BARBOSA, FAR. (Coord.). Relatório Técnico-Científico das atividades de janeiro a dezembro 2004 Pesquisas Ecológicas de Longa Duração (PELD-CNPq) - Sitio 04. Available from: http://www.icb.ufmg.br/peld/ufmg/

MATSUMURA-TUNDISI, T. 1997. Composition and vertical distribution of zooplankton in Lake Dom Helvécio. In TUNDISI, JG. and SAIJO, Y. (Eds.). Limnological studies on the Rio Doce Valley Lakes, Brazil. Brazilian Academy of Sciences; University of São Paulo, School of Engineering at São Carlos, Center for Water Resources and Applied Ecology. p. 266-274.

MATSUMURA-TUNDISI, T. and TUNDISI, JG., 1986. Biomass and zooplankton comunity struture of three lakes of river Doce Valley (MG-Brazil). In WATANABE S. (Org.). Fifth Japan-Brazil Symposium on Science and Technology (Supplement). Tokyo: Japan. p. 35-43.

MORETO, EM., 2001. Diversidade zooplanctônica e variáveis limnológicas das regiões limnética e litorânea de cinco lagoas do Vale do Rio Doce-MG, e suas relações com o entorno. São Carlos: Universidade Federal do São Carlos - UFSCar. 310 p. [Master Dissertation]

PINTO-COELHO, RM., PINEL-ALLOUL, B., MÉTHOT, G. and HAVENS, K., 2005. Crustacean zooplankton in lakes and reservoirs of temperate and tropical regions: variations with trophic status. Can. J. Fish. Aquat. Sci., vol. 61, no. 2, p. $348-361$

RICCIARDI, A., 2003. Predicting the impacts of an introduced species from its invasion history: an empirical approach applied to zebra mussel invasions. Fresh. Biol., vol. 48, no. 6, p. $972-981$.

ROCHA, O. and MATSUMURA-TUNDISI, T., 1997. Respiration rates of zooplankton community of epilimnion and metalimnion layers of Lake Dom Helvécio during stratified and overturn periods. In: TUNDISI, JG. and SAIJO, Y. (Eds.). Limnological Studies on the Rio Doce Valley Lakes, Brazil. Brazilian Academy of Sciences; University of São Paulo, School of Engineering at São Carlos, Center for Water Resources and Applied Ecology. p. 286-296.

SANTOS, LC., 1980. Estudos das populações de Cladocera em cinco lagos naturais (Parque Estadual do Rio Doce) que se encontram em diferentes estágios de evolução. São Carlos: Universidade Federal de São Carlos. 260 p. [Master Dissertation].

SIMON, KS. and TOWNSEND, CR., 2003. Impacts of freshwater invaders at different levels of ecological organisation, with emphasis on salmonids and ecosystem consequences. Fresh. Biol., vol. 48, no. 6, p. 982-994.

SOTO, D., ARISMENDI, I., GONZÁLEZ, J., SANZANA, J., JARA, F., JARA, C., GUZMAN, E. and LARA, A., 2006. 
Southern Chile, trout and salmon country: invasion patterns and threats for native species. Rev. Chil. Hist. Nat., vol. 79, no. 1, p. $97-117$.

TUNDISI, JG., MATSUMURA-TUNDISI, T., FUKUARA, H., MITAMURA, O., GUILLÉN, SM., HENRY, R., CALIJURI, MC., IBAÑEZ, MSR., ESPÍNDOLA, ELG. and GOVONI, S., 1997. Limnology of fifteen lakes. In TUNDISI, JG. and SAIJO, Y. (Eds.). Limnological studies on the Rio Doce Valley Lakes, Brazil. Brazilian Academy of Sciences; University of São
Paulo, School of Engineering at São Carlos, Center for Water Resources and Applied Ecology. p. 409-439.

UTERMÖHL, H., 1958. Perfeccionamento del metodo cuantitativo del fitoplancton. Commun. Assoc. Int. Limnol. Theor. Appl., vol. 9, no. 1, p. 1-89.

WISSEL, B., FREIER, K., MULLER, B., KOOP, J. and BENDORF, J., 2000. Moderate planktivorous fish biomass stabilizes biomanipulation by suppressing large invertebrate predators of Daphnia. Arch. Hydrobiol., vol. 149, no. 2, p. 177-192. 